\title{
Experiment for Regional Sources and Sinks of Oxidants (EXPRESSO): An overview
}

\author{
R. A. Delmas, ${ }^{1}$ A. Druilhet, , B. Cros, ${ }^{1}$ P. Durand, ' C.Delon, ${ }^{1}$ J. P. Lacaux, ' J.M. \\ Brustet, ${ }^{1}$ D. Serça, ${ }^{1}$ C. Affre, ${ }^{1}$ A. Guenther, ${ }^{2}$ J. Greenberg, ${ }^{2}$ W. Baugh, ${ }^{2}$ P. \\ Harley, ${ }^{2}$ L. Klinger, ${ }^{2}$ P. Ginoux, ${ }^{2}$ G. Brasseur, ${ }^{2}$ P. R. Zimmerman, ${ }^{3}$ J. M. \\ Grégoire, ${ }^{4}$ E. Janodet, ${ }^{4}$ A. Tournier, ${ }^{4}$ P. Perros, ${ }^{5}$ Th. Marion, ${ }^{5}$ A. Gaudichet, ${ }^{5}$ \\ H.Cachier, ${ }^{6}$ S. Ruellan, ${ }^{6}$ P. Masclet, ${ }^{7}$ S. Cautenet, ${ }^{8}$ D. Poulet, ${ }^{8}$ C. Bouka Biona, ${ }^{9}$ \\ D. Nganga, ${ }^{9}$ J. P. Tathy, ${ }^{9}$ A. Minga, ${ }^{9}$ J. Loemba-Ndembi, ${ }^{9}$ and P. Ceccato ${ }^{10}$
}

\begin{abstract}
This paper presents an overview of the Experiment for Regional Sources and Sinks of Oxidents (EXPRESSO) including the objectives of the project, a detailed description of the characteristics of the experimental region and of field instrumentation deployed, and a summary of the main results of all components of the experiment. EXPRESSO is an international, multidisciplinary effort to quantify and better understand the processes controlling surface fluxes of photochemical precursors emitted by vegetation and biomass burning along a tropical forest to savanna gradient in central Africa. The experiment was conducted at the beginning of the dry season in NovemberDecember 1996. Three main research tools were deployed during this period: (1) the French research aircraft (Avion de Recherche Atmosphérique et de Télédétection, Fokker 27), instrumented for chemistry and flux measurements (CNRS- France), (2) two satellite receivers for in situ acquisition of National Oceanic and Atmospheric Administrationadvanced very high resolution radiometer (NOAA-AVHRR) imagery for fire detection (EC-JRC, Ispra, Italy), and (3) a 65-m walkup tower installed at a tropical forest site in the Republic of Congo (National Center for Atmospheric Research, Boulder, Colorado). Average dynamic and turbulence characteristics over savanna and forest ecosystems were retrieved from aircraft measurements. They illustrate the complex atmospheric circulation occurring in this region in the vicinity of the Intertropical Convergence Zone. Satellite receivers were operated three times a day to produce maps of fire distribution. Statistics and mapping of burned surfaces from NOAA-AVHRR and ERS-Along Track Scanning Radiometer space systems have been developed. The influence of biogenic and biomass burning sources on the chemical composition of the lower atmosphere was studied through both aircraft and tower measurements. The EXPRESSO field campaign was followed by modeling efforts (regional and global scales) in which model components are evaluated using the experimental data.
\end{abstract}

\section{Introduction}

The Experiment for Regional Sources and Sinks of Oxidants (EXPRESSO) is an international and

\footnotetext{
'Laboratoire d'Aérologie, OMP, Toulouse, France.

${ }^{2}$ National Center For Atmospheric Research, Boulder, Colorado.

${ }^{3}$ Institute of Atmospheric Sciences, Rapid City, South Dakota.

${ }^{4}$ Space Application Institute, Monitoring Tropical Vegetation Unit, Ispra, Italy.

${ }^{5}$ Laboratoire Interuniversitaire des Sciences de l'Atmosphère,

Faculté de Sciences, Université Paris XII, Créteil, France.

${ }^{6}$ Laboratoire des Sciences du Climat et de l'Environnement, Bât 12, Campus CNRS, Gif sur Yvette, France.

${ }^{7}$ Laboratoire d'Etude des Systèmes Atmosphériques Multiphasiques, ESIGEC, Université de Savoie, Le Bourget du Lac, France.

${ }^{8}$ Laboratoire Associé de Météorologie Physique, Université Blaise Pascal, Aubière, France.

${ }^{9}$ Université de Brazzaville, Brazzaville, Congo.

${ }^{10}$ Natural Resources Institute, Chatham, England, U.K

Copyright 1999 by the American Geophysical Union.
}

Paper number 1999JD900291.

0148-0227/99/1999JD900291\$09.00 multidisciplinary program designed to investigate processes controlling chemical composition of the tropical troposphere above central Africa and consider the impact on the global atmosphere. Biomass burning, ubiquitous in African savanna, exerts a dominant influence on ecology and atmospheric chemistry. Biogenic fluxes of reactive trace gases are concentrated in tropical land areas. The high surface fluxes observed in the tropics are likely to influence the global atmosphere due to strong vertical mixing. The impact of human activities on trace gas fluxes in the tropics is significant (e.g., biomass burning, deforestation) and is expected to increase due to current high rates of population growth. Preliminary EXPRESSO experiments were completed in January 1994 and 1995, November 1995 and March 1996, with the major field intensive being conducted in November and December 1996. The EXPRESSO domain extends from the savannas of southern Chad in the north $\left(12^{\circ} \mathrm{N}\right)$ to the tropical forests of the Republic of Congo $\left(2^{\circ} \mathrm{N}\right)$ in the south. Several types of investigations were conducted during this experiment. The Avion de Recherche Atmosphérique et de Télédétection (ARAT) research aircraft (Fokker 27), equipped for measuring atmospheric dynamics, 
radiation, and chemistry, was the basic tool used. It conducted 11 missions out of Bangui (Central African Republic) overflying a range of ecosystems from savanna to tropical forest. A detailed database of the extent of biomass burning in central Africa during the EXPRESSO experiment was compiled using National Oceanic and Atmospheric Administration-advanced very high resolution radiometer (NOAA-AVHRR) data (three acquisitions per day). A landscape-level emission potential database for volatile organic compounds (VOC) is being developed based on NOAA-AVHRR landcover data, ground surveys of vegetation type, and a vegetation VOC emission rate database. A $60-\mathrm{m}$ walkup tower, providing access to the canopy, was installed at a nearly undisturbed tropical forest site in the northern Congo forest. It was used to study both forest microclimate and trace gas fluxes (especially VOC). EXPRESSO is expected to result in improved surface trace gas emission submodels for central Africa that can be incorporated into global Earth system models. In addition, EXPRESSO measurements will be used to evaluate and improve our understanding of the production and loss of tropospheric oxidants within this region through regional scale modeling.

\section{Scientific Background and Objectives}

Tropical biomes exhibit some of the most dynamic, yet most poorly understood biogeochemistry on Earth. The tropics contain $40 \%$ of the global land mass and account for about $60 \%$ of the global annual net primary productivity (NPP) [Rodin et al., 1975]. This high productivity is characterized by a diversity of plant species which is unparalleled at any other latitudes. It has been estimated that tropical forests include $66 \%$ of all plant and animal species; many of which have yet to be described [Raven, 1988]. This high productivity is fueled by large inputs of solar energy and by the transformation of this energy into latent and sensible heat, which recycles moisture in complex but predictable meteorological regimes. These factors also make tropical regions extremely important with respect to global atmospheric dynamics. Heat and moisture drive most biogeochemical cycles including NPP and carbon turnover, to which trace gas fluxes are often closely coupled, and fluxes of many trace gas species into and out of tropical ecosystems are expected to be high.

Field campaigns conducted in the last 15 years have confirmed the importance of the tropics on the regional and global composition and chemistry of the atmosphere. Biomass burning was shown to be important by the Quemadas studies in Brazil in 1979 and 1980 [Crutzen et al., 1985]. The Global Tropospheric Experiment/ Atmospheric Boundary Layer Experiment (GTE/ABLE 2A and $2 \mathrm{~B}$ ) in Amazonia further defined the regional chemical composition of the Amazon basin during both wet and dry seasons [Harriss et al., 1988]. In Africa, studies have been done in the Congo and the Ivory Coast as part of the Dynamique et Chimie Atmosphérique en Forêt Equatoriale (DECAFE) program [Fontan et al., 1992; Lacaux et al., 1995, and references therein]. Recently, additional studies have been completed in South America during the South Tropical Atlantic Regional Experiment/Transport and Atmospheric Chemistry Near the Equator-Atlantic (STARE/TRACE-A) missions [Lindsay et al., 1996], and in
South Africa as part of TRACE-A/Southern African FireAtmosphere Research Initiative (SAFARI) [Fishman et al., 1996]. Together, these studies have shown the following:

Biomass burning associated with agricultural activity in the savanna, the destruction of tropical forests, and the use of wood as fuel releases into the atmosphere large quantities of carbon dioxide and a variety of chemically active species such as $\mathrm{CO}$, odd nitrogen $\left(\mathrm{NO}_{\mathrm{x}}\right), \mathrm{N}_{2} \mathrm{O}, \mathrm{CH}_{4}, \mathrm{VOC}$, methyl chloride $\left(\mathrm{CH}_{3} \mathrm{Cl}\right)$, and others [Crutzen et al., 1985; Greenberg et al., 1984]. Global annual biomass burning represents about 1.8 to $4.7 \mathrm{Gt}$ of carbon burned [Crutzen and Carmichael, 1993], with savanna fires being the dominant component (about 1- $1.6 \mathrm{Gt}$ of carbon burned). Savanna fires alone contribute approximately $10 \%$ of global CO emissions and $25 \%$ of global emissions of carbonaceous particulates [Liousse et al., 1996]. This phenomenon is especially important in Africa, where the contribution of savanna fires to global emissions of trace gasses and aerosols has been estimated by Lacaux et al. [1993] to be equal to $30 \%$ of total biomass burning emissions.

Grassland and savanna soils release quantities of nitrogen oxides [Johansson and Sanhueza, 1988] which, although poorly quantified, are probably sufficient in the presence of hydrocarbons to contribute to substantial amounts of $\mathrm{O}_{3}$ production. Large quantities of $\mathrm{NO}_{\mathrm{x}}$ have been observed in plumes of savanna fires [Crutzen et al., 1985; Delmas et al., 1995]. Hydrocarbons are emitted by many biological sources, notably the tropical forest canopy, from which VOC emissions are expected to be dominated by isoprene [Zimmerman et al., 1988; Guenther et al., 1995].

Evidence for the impact of fires on atmospheric chemistry has come first from satellite data obtained from the Total Ozone Mapping Spectrometer (TOMS) and the Stratospheric Aerosol and Gas Experiment (SAGE) between 1979 and 1989 [Fishman and Larsen, 1987]. The tropospheric data have shown a well-defined maximum in $\mathrm{O}_{3}$ of more than 45 Dobson Units $\left(1 \mathrm{DU}=2.69 \times 10^{16}\right.$ molecules of $\mathrm{O}_{3}$ per square centimeter) off the west coast of Africa during September and October [Fishman et al., 1990]. Tropospheric $\mathrm{O}_{3}$ data obtained from ozone sondes, launched over a 2 year period at Brazzaville, Congo $\left(4^{\circ} \mathrm{S}\right)$, show a maximum of 45 DU between July and September during the fire season in southern Africa [Cros et al., 1992; Nganga et al., 1996]. The atmospheric mechanisms leading to $\mathrm{O}_{3}$ formation over the tropical Atlantic were well documented during the TRACE-A experiment in 1992 [Fishman et al., 1996]. More than 50 papers published in a special issue of the Journal of Geophysical Research, 10I(D19), 1996, demonstrate the important impact of tropical sources of trace gas and aerosol on the chemical composition of the atmosphere.

In nonurban areas, compounds released by the biosphere through biogenic or combustion processes constitute the basic mixture for photochemistry, which determines the cycle of oxidants in the troposphere, including the transformation of unstable primary products into more stable secondary products. These compounds can be transported in air masses away from source regions and thus affect the chemical composition of the atmosphere on regional and global scales. Furthermore, vertical $\mathrm{O}_{3}$ profiles typically reveal discrete layers of high $\mathrm{O}_{3}$ concentrations at altitudes between 1 and 5 km [Marenco et al., 1990]. This layered vertical structure indicates the importance of convective transport in the 
distribution of primary and secondary products of biomass burning. Coupled with emissions associated with biomass burning, the release of volatile species by soils and vegetation contributes directly to the photochemical production of reactive chemical species.

Cloud convection favors vertical exchanges from the boundary layer to the upper troposphere, and thus long-range transport of trace compounds coming from the continental biosphere. During TRACE-A, a series of large mesoscale convective systems that occurred during the Brazilian phase provided an opportunity to observe deep convective transport of trace gases from biomass buming. Large enhancements of $\mathrm{CO}, \mathrm{NO}_{\mathrm{x}}$, and hydrocarbons were observed in cloud outflow at 9-12 km altitude leading to postconvection $\mathrm{O}_{3}$ formation in the middle and upper troposphere [Pickering et al., 1996]. Jacob et al. [1996] proposed a global schema of $\mathrm{O}_{3}$ behavior in the tropical troposphere. In this model, the large-scale circulation of the tropical atmosphere is represented by the Walker cells. The transfer of surface air masses containing $\mathrm{O}_{3}$ precursors $\left(\mathrm{CO}, \mathrm{VOC}\right.$, and $\mathrm{NO}_{\mathrm{x}}$ produced by continental sources with additional $\mathrm{NO}_{\mathrm{x}}$ from lightning) occurs by deep convection over the continents in the rising branches of the Walker cells, driving $\mathrm{O}_{3}$ production in the middle and upper troposphere. Moreover, the most intense convective systems can cross the tropopause and inject directly into the stratosphere chemical compounds originating from surface sources such as $\mathrm{CH}_{4}, \mathrm{NO}_{x}$, and $\mathrm{N}_{2} \mathrm{O}$. These constituents have a direct impact on the stratospheric $\mathrm{O}_{3}$ layer.

In addition, chemical transformations in this region are achieved through both gas phase and heterogeneous processes. Heterogeneous processes (i.e., multiphase chemical reactions between gases and liquid or solid particles) are especially important in the equatorial zone due to the high aerosol load in the lower atmosphere, the extent of cloud coverage, and the intensity of convective activity. Haze and high levels of acidic precipitation are reported in remote tropical regions [Lacaux et al., 1992]. During the dry season, pollution events are similar in magnitude to those observed in industrialized regions. In Africa, for instance, high levels of acidity (organic and inorganic), and high particulate black carbon content in precipitation, related to biomass burning, are observed [Cachier and Ducret, 1992]. In the northern Congo forest, close to the savanna zone, the yearly average value of rainwater $\mathrm{pH}$ is as low as 4.4 . It is estimated that $86 \%$ of this acidity results from biomass burning which releases both organic acids [Helas et al., 1992] and nitrogen oxides, the latter being precursors of nitric acid in the atmosphere [Lacaux et al., 1991, 1993]. The consequences of this acid precipitation, resulting from biosphere-atmosphere exchanges, on regional scales are still unknown.

It is clear that ecological succession, disturbance, and human-induced land use change are intense in the tropics. These processes affect vegetation species composition, soil microbiology, nutrient cycling, and the radiation balance of ecosystems [Nicholson, 1992]. These in turn affect trace gas emissions that impact the Earth's radiation balance and cleansing capacity (oxidant balance) [Keller et al., 1993]. The magnitude of these changes and the regional and global impacts are unknown.

EXPRESSO is an interdisciplinary experiment designed to better quantify important flux processes over a range of spatial scales and to estimate their impact locally, regionally, and globally. It is a component of the International Global Atmospheric Chemistry (IGAC) project. The field campaign represents an international collaboration led by European (CNRS, France, and JRC, European Community, Ispra, Italy) and U.S. scientists (National Center for Atmospheric Research (NCAR), Boulder, Colorado), and conducted in collaboration with African scientists from Brazzaville and Bangui Universities.

The scientific questions addressed by the EXPRESSO project include the following: (1) What are the exchange rates of reactive trace gases and aerosols between the tropical biosphere and the atmosphere? (2) Are there significant chemical interactions between the savanna and the tropical forest? (3) What are the respective roles of photochemical and meteorological processes in determining the chemical composition of the atmosphere above central Africa? (4) How are trace gas fluxes influenced by ecological processes? and (5) What is the impact of tropical sources on the global troposphere?

To address these questions, an experimental program has been implemented to quantify fluxes of numerous chemical species over a range of spatial scales from the individual leaf, branch, and soil surface up to landscape and regional scales. The experimental design included an intensively studied ground station equipped with a fully instrumented tower, complemented by detailed characterization of vegetation. Regional survey flights and aircraft measurements along transects between savanna and forest served to (1) monitor the meteorology of the regional atmosphere and investigate vertical transfer mechanisms from the surface to the boundary layer and the free troposphere; (2) characterize the chemical interactions between emissions from the savanna and the forest; and (3) assess how representative the intensive local site measurements are of the entire savanna and forest ecosystems.

The campaign also focused on the fate of compounds released by the biosphere into the atmosphere. For example, we tried to quantify $\mathrm{O}_{3}$ formation and deposition, and active nitrogen consumption under a range of conditions. Investigations include an examination of spatial distribution and chemical composition of aerosols.

\section{Experimental Region}

\subsection{General}

The EXPRESSO campaign was conducted in central Africa over an area of about $1000 \times 1000 \mathrm{~km}$ in the northwestern part of the Congo river basin. The experimental region is covered by open forest formations, shrubby and grassy savanna in the Central African Republic (CAR), and dense equatorial forest in the northern Congo. Research sites were located in the savanna near Bangui (CAR) and in the forest of the northern Congo (Bomassa $2^{\circ} 12.25 \mathrm{~N}, 16^{\circ} 11.2^{\prime} \mathrm{E}$ ).

\subsection{General Meteorological Situation in Central Africa}

The general meteorological situation over Africa is driven by three permanent anticyclones, located on the northwest (Azores/Canary Islands), southwest (Saint Helena), and southeast (Madagascar). The air masses originating from these anticyclones converge along the Intertropical Convergence Zone (ITCZ) which separates the southern 


\section{January - 925 hPa}

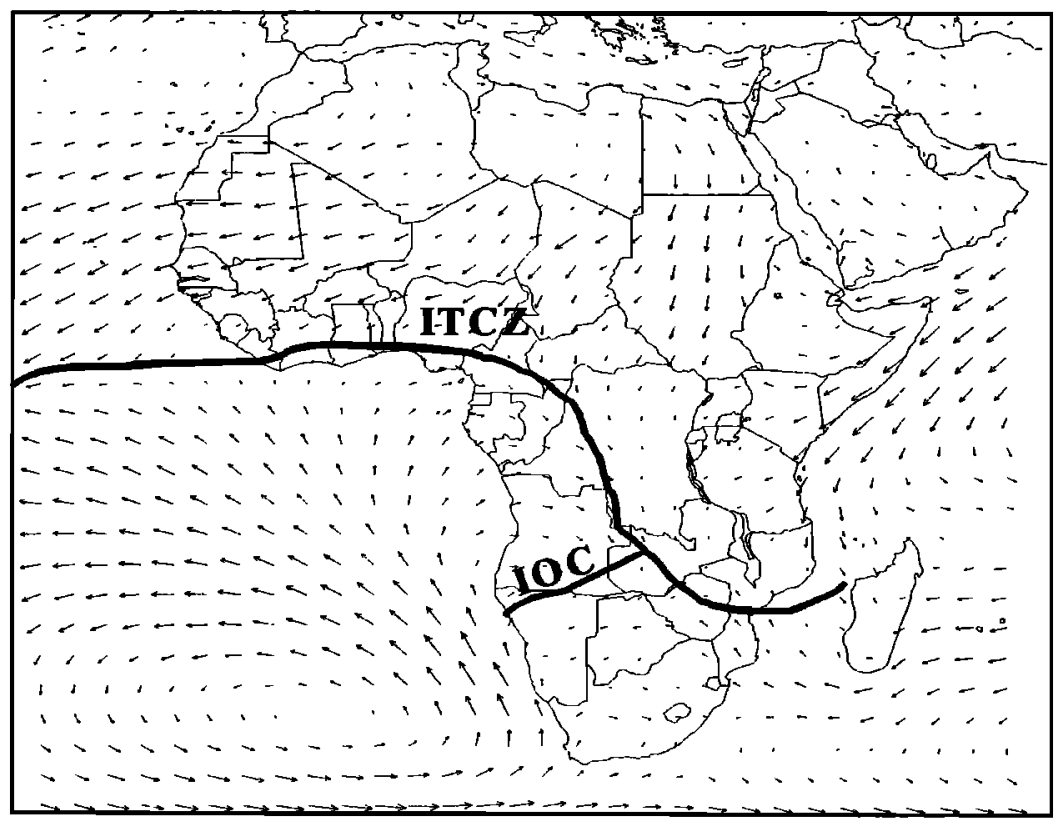

\section{July - 925hPa}

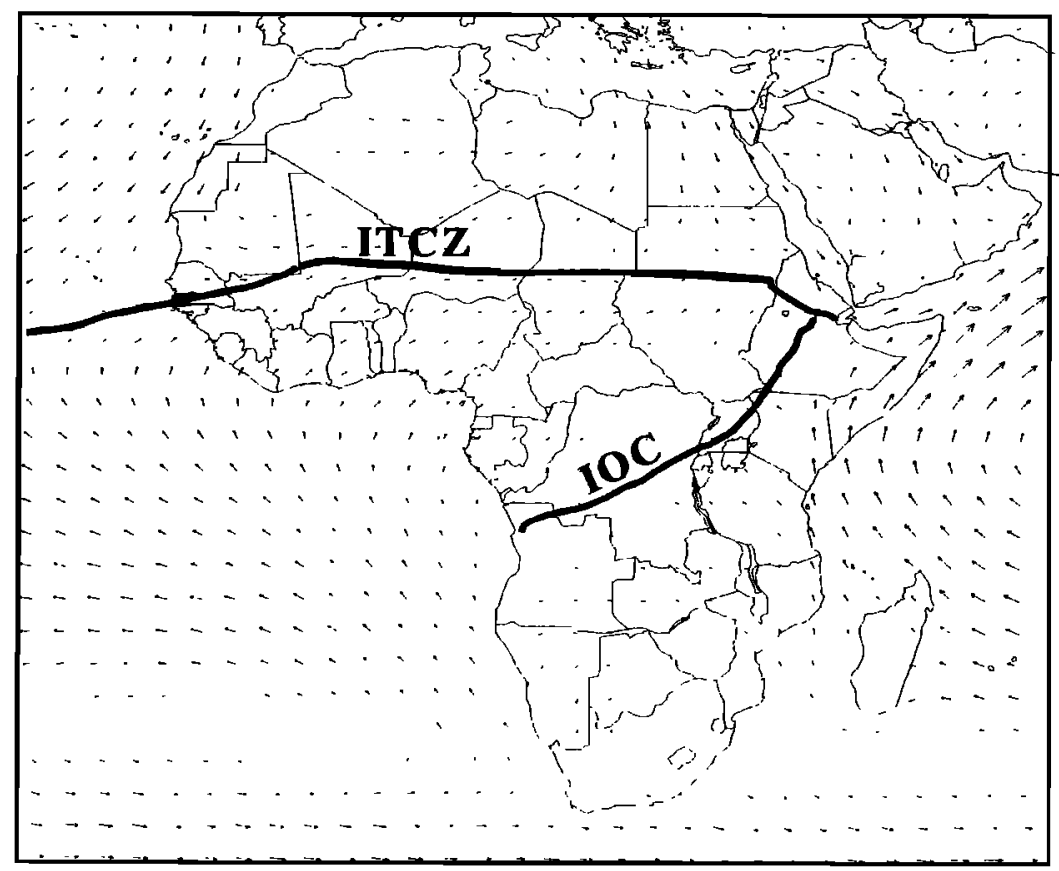

Figure 1. General meteorological circulation over Africa in January and July.

winds from the northern winds at $900 \mathrm{mbar}$, and the Intertropical Oceanic Confluence (IOC), separating the western and the eastern winds at 900 mbar. A low-level monsoon flux of moist air driven by the Saint Helena anticyclone is trapped along the convergence zones by the high-altitude warm air originating in the north and southeast. The warm monsoon flow produces a large zone of convective clouds bounded by the ITCZ and IOC. Thus the shift in the position of the ITCZ and IOC during the year determines the different rainfall regimes. Because of its position, west of the $I O C$, the Congo is influenced only by the north trade "Harmattan" winds and the monsoon flux (Figure 1).

In the vicinity of the convergence zone, the monsoon layer is thin, while 1000 to $2000 \mathrm{~km}$ farther south, it reaches its maximum depth and produces abundant rainfall. During the austral winter (June to September), the low sea surface temperatures in the Gulf of Guinea produce thermal stability. This thermal stability decreases as the monsoon flux moves 


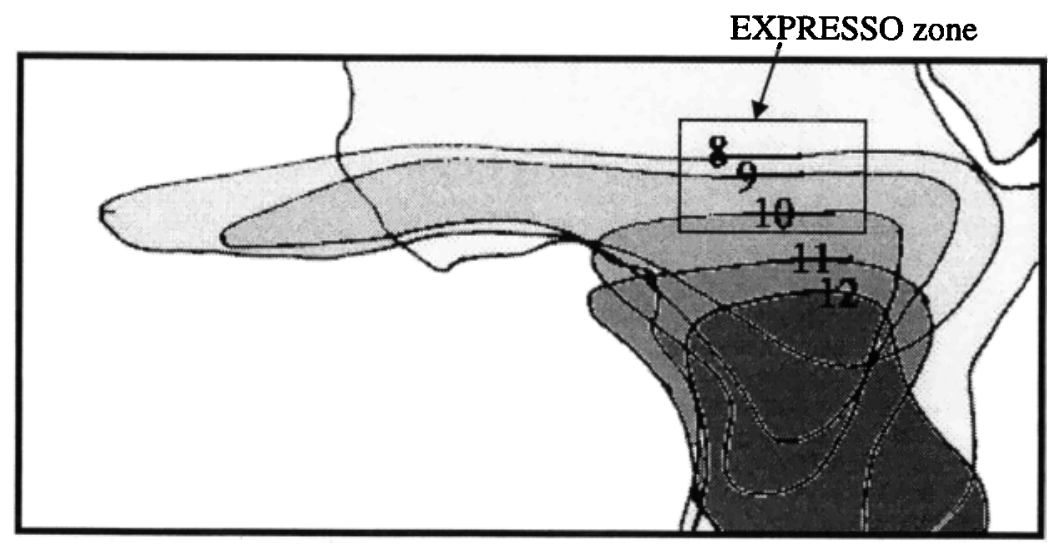

Figure 2. Evolution of the Intertropical Convergence Zone (ITCZ) from July to December 1996. The surface occupied by the elevated clouds in July corresponds to a thin zonal band from the Atlantic Ocean to the African east coast. It widens on the African continent and decreases its zonal spreading in order to only occupy the central part of equatorial Africa. The length of this zonal band decreases from July to December, and its superior limit strongly falls in latitude. The limits of the cloudy zone are located on the continent and next to the Central African Republic (CAR). The evolution of the northern limit of the band has a velocity of $2 \mathrm{~cm} / \mathrm{s}$ in July and $20 \mathrm{~cm} / \mathrm{s}$ in October (maximum velocity). In November and December, the evolution is null, the ITCZ is stabilized between $2^{\circ}$ and $3^{\circ} \mathrm{N}$, and its zonal extension is minimum. (The numbers correspond to the months of the year.)

over the continent and the ITCZ reaches its northernmost position $\left(20^{\circ} \mathrm{N}\right)$. For the northern part of the Congo, this corresponds to the wet season when convective activity reaches its maximum, and high precipitation is observed. In October, the ITCZ moves southward, toward its southernmost position $\left(8^{\circ} \mathrm{N}\right)$ in January. This is illustrated in Figure 2, which shows the deep convection area deduced from satellite remote sensing observations (Meteosat) of convective clouds between August and December 1996. Over the northern part of the Congo, convective activity is then scarce, rainfall is reduced, and the season corresponds to the dry season. The intensity of the monsoon is reduced during January and February as the ITCZ reaches its southernmost location, but increases again in March and April as the ITCZ is displaced toward the north. In Bangui, north of the equator, the main dry season occurs from December to February when the ITCZ is located at its southernmost position and the Harmattan (dry wind from the Sahara) blows from the desert. The rainy season lasts from April to November with a slight interruption in June corresponding to the dry season south of the equator.

\subsection{Ecosystems and Climate in the Experimental Region}

The amount of annual rainfall and the length of the dry period largely determine the type of vegetation. Two major ecosystems are distinguished: the equatorial forest zone and the savanna zone. The northem part of the Congo is covered by tropical forest, while the savanna appears farther north (Central African Republic). Because there is relatively little relief, the vegetation falls into natural latitudinal zones determined by regional climate patterns (Figure 3, after White [1983]). Seasonal temperature fluctuations are small, and although edaphic factors may introduce variation on a local scale, the amount and timing of rainfall assumes overriding importance in defining these zones of potential vegetation. Generally speaking, rainfall is maximal and most evenly distributed near the equator, although some seasonality is apparent even here; as one moves north from the equator, the amount of annual rainfall decreases, and the dry season becomes more distinct and longer in duration. Figure 4 illustrates the gradients in both temperature and precipitation between the two stations of Ouesso $\left(1^{\circ} 37 \mathrm{~N}\right)$ located in the primary forest zone and Bangui $\left(4^{\circ} 23 \mathrm{~N}\right)$ in the savanna-forest transition zone.

The large area extending from $4^{\circ} \mathrm{S}$ to $4^{\circ} \mathrm{N}$ and from the Atlantic to the lakes and highlands of East Africa is dominated by tropical lowland evergreen forest or swamp forest, depending on drainage. Bomassa, the EXPRESSO forest site, is located in the northern part of the moist forest zone, where periods of dryness are more common than in the Zaire basin, for example. Where the moist forest zone is relatively undisturbed, there is a continuous canopy at a height of $30 \mathrm{~m}$ or more, with emergent trees rising to 40 or $50 \mathrm{~m}$. These forests are generally characterized as evergreen or semievergreen, although a substantial fraction of tree species are deciduous [Hamilion, 1989]. Although small patches occur within the lowland moist forest region which are dominated by a single (sometimes two) tree species, the forests are generally quite heterogeneous. Species diversity is quite large by African standards (though not compared with Amazonia or Southeast Asia), ranging from 200 to 500 species per hectare [Swaine and Hall, 1986], increasing with increasing rainfall.

As one moves north from Bomassa, annual rainfall progressively decreases, and the duration and intensity of the dry season increase. This is reflected in changes in the vegetation, as largely evergreen forest gradually gives way to forest with a larger deciduous component, then to woodland and dry savanna. The region of Bangui lies near the boundary of two vegetation zones, characterized by White [1983] as a rain forest/secondary grassland mosaic and the dryer Sudanian woodland, characterized by a dry season 


\section{EXPRESSO Ground Sites and Vegetation Zones of Central Africa}
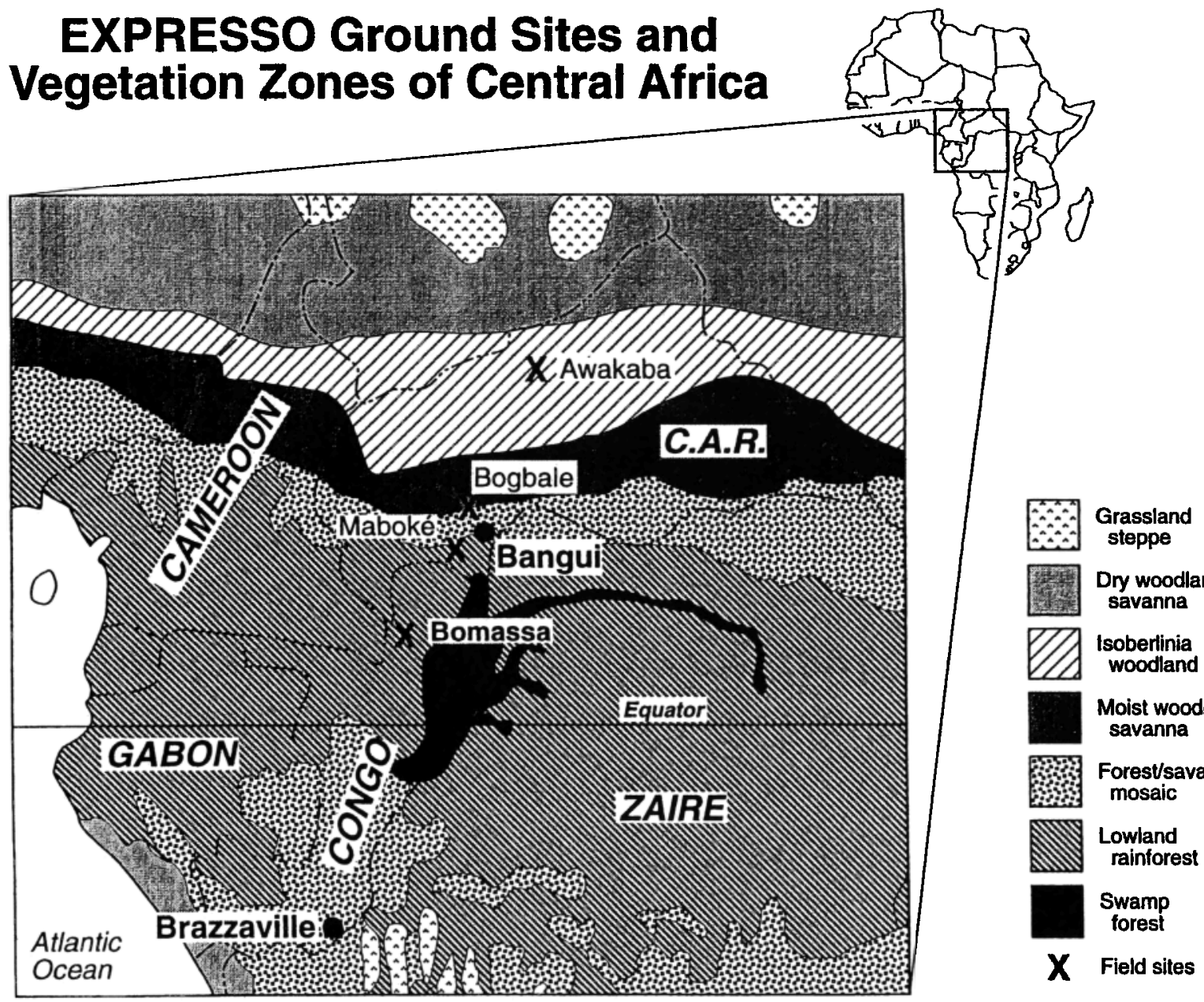

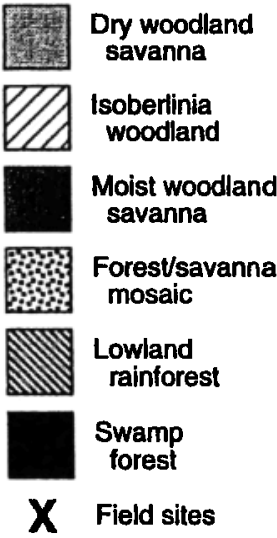

Figure 3. Location of EXPRESSO ground sites and vegetation zones of Central Africa.

lasting at least 5 months. Farther north in the Central African Republic, open woodland (i.e., crowns not touching) of deciduous trees and shrubs is typical, interspersed with areas of tall grass [Steentoft, 1988]. The leaf area index (LAI; $\mathrm{m}^{2}$ leaf area $/ \mathrm{m}^{2}$ soil area) was measured along a savanna-rainforest transect in Central Africa during preEXPRESSO campaigns in 1995 and 1996 [Klinger et al., 1998], and merged with satellite (NOAA-AVHRR) optical data [Braswell et al., 1996]. LAI varies from less than 2 in savanna and agricultural zones up to 6 in the rain forest, with a tree cover of $60 \%$ in woodland savanna, $80 \%$ in Isoberlinia forest, and $100 \%$ in rain forest (Figure 5, from Klinger et al., [1998])

Throughout the region of study, the vegetation composition and structure has long been influenced by human activity. Little undisturbed rain forest remains, and secondary grasslands and various stages of forest regrowth are extensive. Much of the transition between forest and savanna (often described as a forest/savanna mosaic) was formerly continuous rain forest and reverts to forest if protected from cutting and fire. The savanna woodlands are particularly influenced by human activity, with large areas burned each year during the dry season, helping to maintain an open shrubland or grassland.

\subsection{Trace Gas and Aerosol Sources and Their Impact on the Atmosphere}

In the experimental region, due to the very low population density and low level of development, anthropogenic pollution associated with fossil fuel combustion is limited, and atmospheric chemistry is largely dominated by biosphere-atmosphere exchanges. The main sources of trace gases and aerosols are biogenic emissions from soils and vegetation, and biomass burning, mainly savanna fires which are mostly anthropogenic.

Biogenic processes mainly lead to emissions of hydrocarbons from the canopies of both tropical forest and woody savanna [Klinger et al., 1998], nitrogen compounds from soils in savanna and forest, and methane in the flooded forest area which covers more than $10^{5} \mathrm{~km}^{2}$ in the experimental zone. Vegetation fires have been shown to produce, in various proportion, almost all reactive or radiatively active trace gases, and aerosols. Owing to the chemical composition of the phytomass, emissions are dominated by carbon and nitrogen compounds. Basically, trace compounds emitted by both biogenic and biomass burning sources are similar, however, some of them (e.g., isoprene for biogenic emissions, and CO for combustion) can be used as specific chemical tracers. 

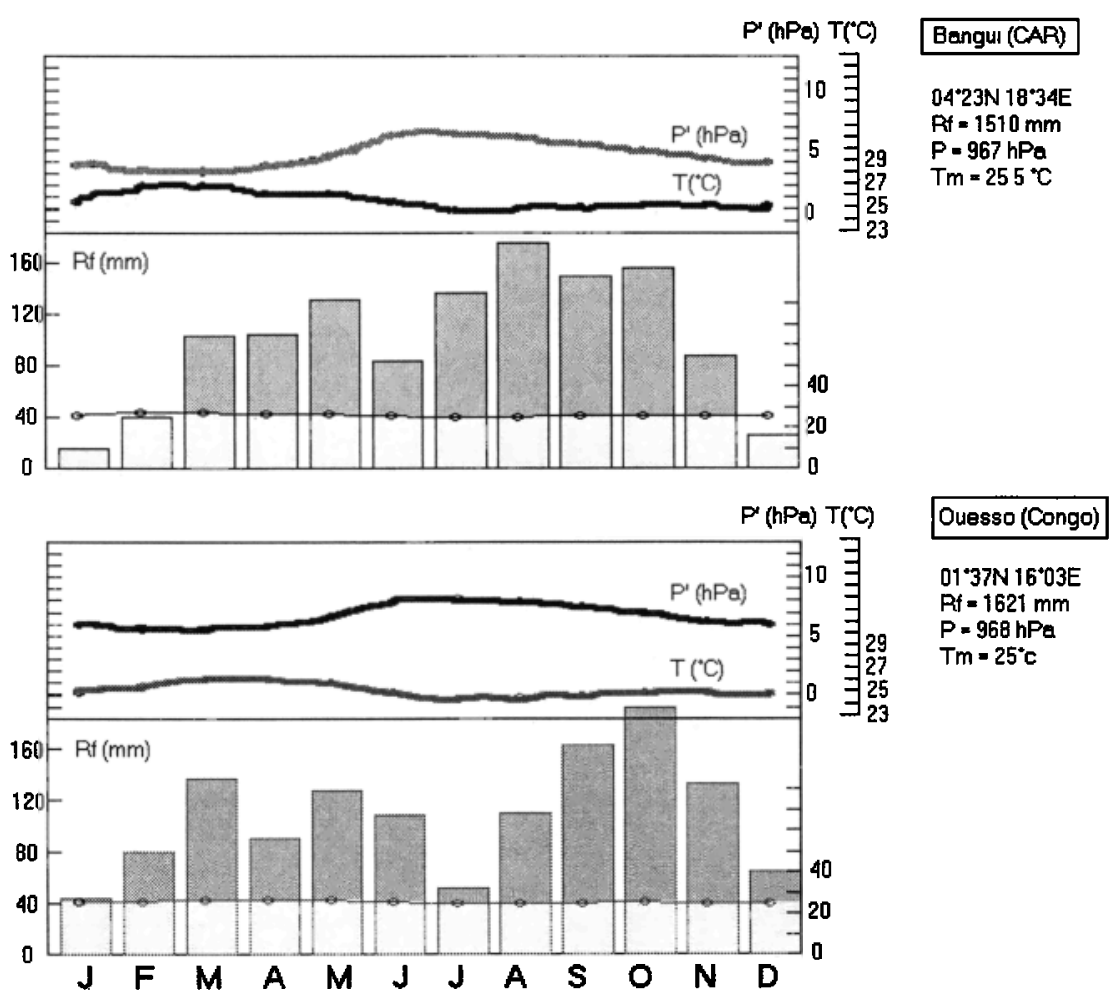

Figure 4. Average pressure, rainfall, and temperature annual cycle at Bangui (CAR) and Ouesso (Congo).

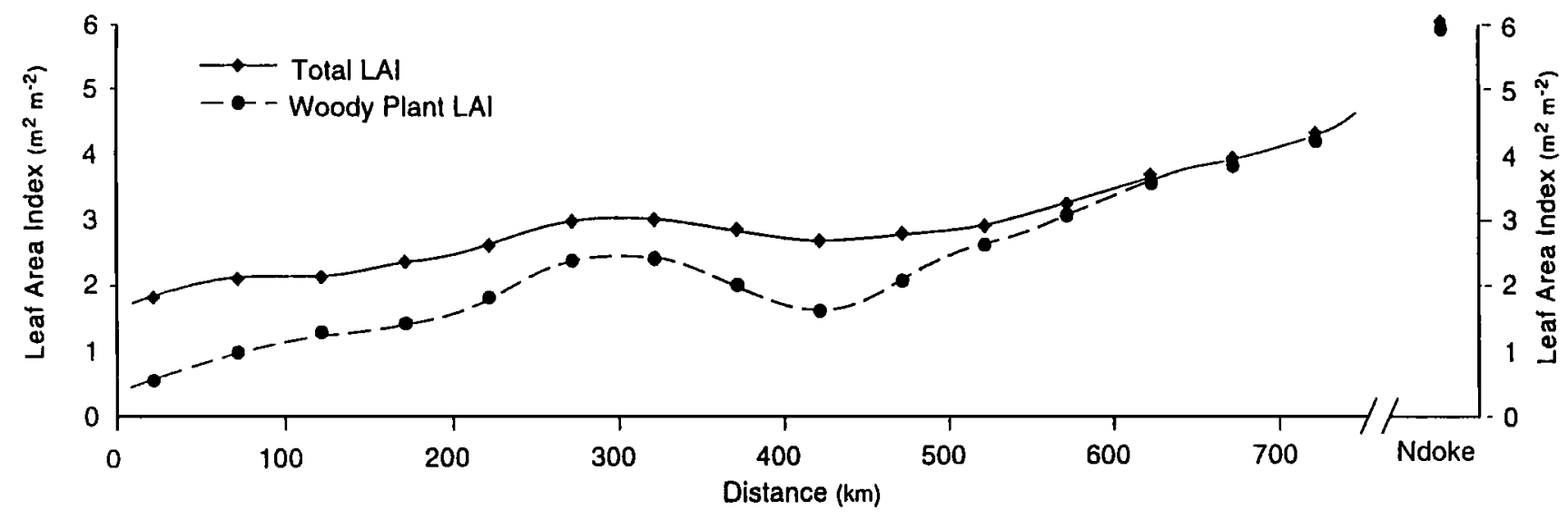

Chad

pressure, rainfill, and temperature annual cycle at Bangui (CAR) and Ouesso (Congo).

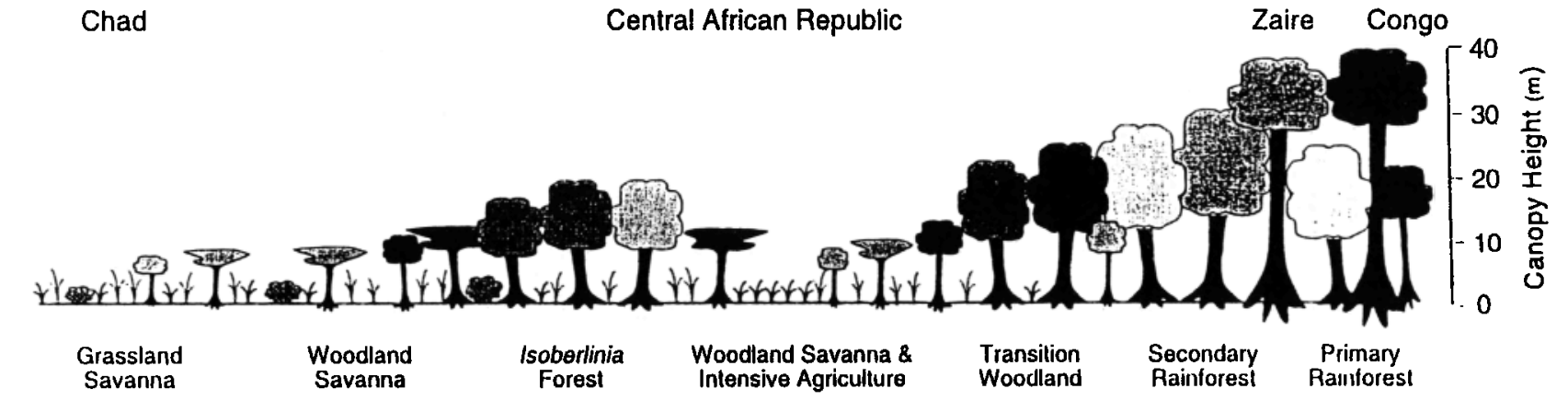

Figure 5. Latitudinal variation of total leaf area index (LAI) and woody plant LAI along a savanna-rain forest transect in the EXPRESSO zone in Central Africa [from Klinger et al., 1998]. 


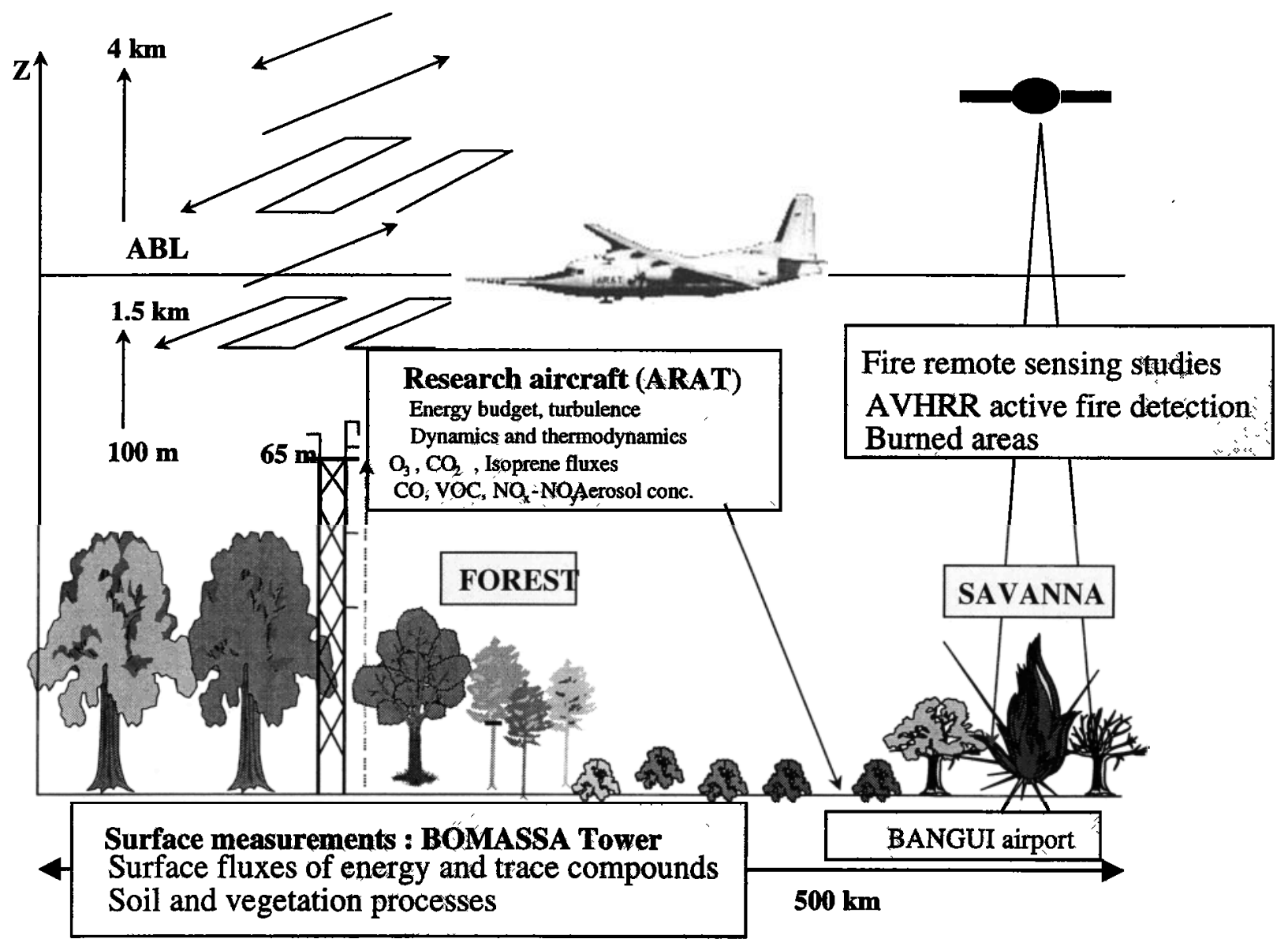

Figure 6. Schematic representation of the EXPRESSO field deployment during the November-December 1996 experiment, showing the main experimental tools used: the research aircraft Fokker 27 (ARAT), the instrumented Bomassa tower and tethered balloon sampling system, and the satellite receiver for detection of savanna fires.

\section{Experimental Setup}

The experimental concept of EXPRESSO is based on the scientific objectives of the project. The intensive campaign took place during the dry season (November-December 1996) when the influence of biomass burning was dominant, leading to active photochemistry fueled by large inputs of hydrocarbons, $\mathrm{CO}$, and nitrogen oxides. This intensive was designed to study the interactions of biomass burning with the tropical forest.

\subsection{Field Studies}

The EXPRESSO intensive of November-December 1996 was preceded by several campaigns in January 1994, January 1995, and November 1995, in which simultaneous satellite, airborne, and field observations were made to calibrate and validate fire detection and burned surface mapping procedures [Ehrlich et al., 1995]. In the meantime, two expeditions were conducted in 1995 and 1996 in the CAR and northern Congo to characterize vegetation distribution and to screen vegetation species for VOC emissions along an $800 \mathrm{~km}$ transect from savanna to rain forest [Klinger et al., 1998].

Experimental tools used are shown in Figure 6. They include a research aircraft (ARAT), an instrumented tower at the Bomassa forest site, and a satellite receiving station located in Bangui.

\subsection{Local Scale}

One ground site was established in the northern Congo forest to obtain local measurements of energy and trace gas fluxes. These measurements characterized seasonal and daily patterns of energy exchange and trace gas emissions and are complimentary to the regional flux estimates obtained using aircraft. A 65-m walkup tower was installed at a nearly undisturbed tropical forest site on the edge of the Nouabale-Ndoki National Park in the Republic of Congo in March 1996. The tower provided access to the forest canopy and the surface layer above the canopy. Nouabale-Ndoki National Park and adjacent forest reserves cover about a million hectares of primary tropical forest, making this region one of the largest protected areas in central Africa. VOC concentrations and fluxes were measured in March and in November/ December 1996 field studies. The relaxed eddy accumulation (REA) method was used to measure isoprene fluxes [Guenther et al., 1996], while $\mathrm{CO}_{2}, \mathrm{H}_{2} \mathrm{O}$, and sensible heat fluxes were measured by the eddy covariance method [Businger and Delany, 1990]. Additional filter and cartridge sarnples were collected for detailed analyses of VOC $\left(\mathrm{C}_{3}\right.$ to $\mathrm{C}_{12}$ ) and aerosols (organic, inorganic, anion/cation). Foliar 
Table 1. List and Specifications of Measurements Performed on and Around the Tower Installed at Bomassa in the Rain forest of the Northern Congo

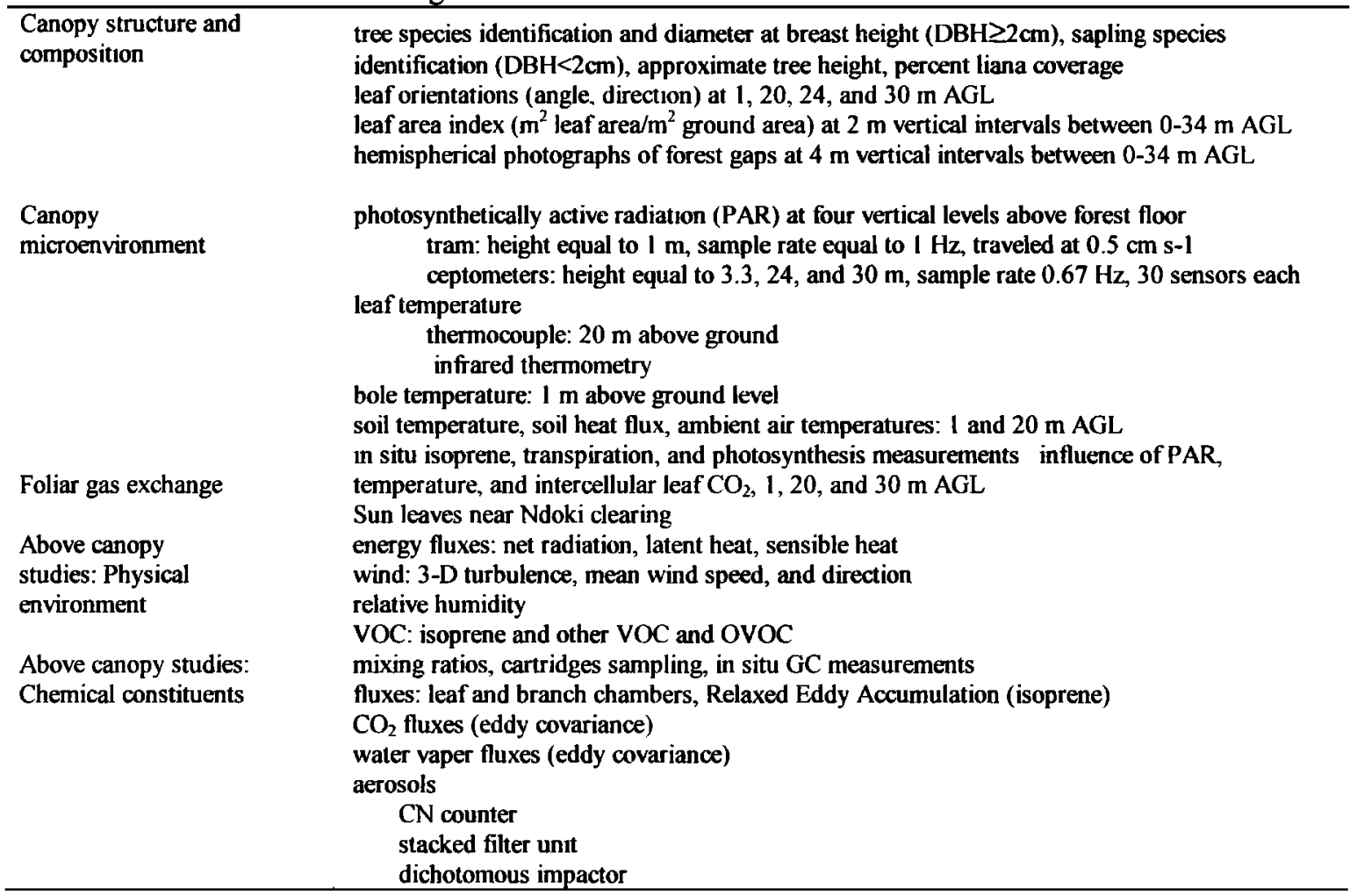

mass and species composition were measured along eight transects radiating out from the tower. Over 130 different plant species were identified. Enclosures were used to measure VOC, $\mathrm{H}_{2} \mathrm{O}$, and $\mathrm{CO}_{2}$ fluxes on leaves of individual plant species so that leaf and canopy scale flux measurements could be compared. A temperature and lightcontrolled leaf enclosure was used to study the response of biogenic VOC emissions to changes in environmental parameters. A detailed study of canopy microclimate was conducted in order to improve canopy environment models needed to scale measurements made on individual leaves to entire canopies. The measurements performed at the Bomassa (Nouabalé-Ndoki) site are summarized in Table 1.

\subsection{Regional Scale}

Measurements from aircraft are the only practical way to characterize the vertical and regional chemical composition of air masses and to document the average dynamic and thermodynamic fields affecting the study areas. These measurements, over a spatial scale of about $500 \mathrm{~km}$ and 0-4 km altitude, associated with a three-dimensional (3-D) mesoscale meteorological model provide information on interaction mechanisms between savanna and forest ecosystems and will enable the partition between direct fluxes associated with the horizontal advection, entrainment at the top of the monsoon layer, and cloud transfers. At this working scale, aircraft also provide the capability to track air parcels as they are advected from source regions and modified by photochemical and depositional processes. Transformations of reactive products such as $\mathrm{O}_{3}$ can be followed in air masses during their transfer from savanna to forest zones.
The aircraft used in this study was the French research aircraft ARAT owned and operated by Institut Géographique National (IGN) and managed by Institut National des Sciences de l'Univers (INSU). The ARAT is a measurement platform with a large spectrum of capabilities (Table 2). Most of sensors are situated in the $6 \mathrm{~m}$ long nose boom, along the fuselage or inside the cabin. Positioning is made with an Inertial Navigation System (INS), a satellite Global Positioning System (GPS), a radioaltimeter, a standard barometer altimeter, and a downward looking video camera. Dynamics measurements use INS and accelerometers to define the aircraft movement relative to the ground. Different sensors are used to calculate the airflow related to the aircraft, pressure, temperature, humidity, and speed fluctuations. The air motion relative to the ground is computed by difference. Many upward and downward radiation sensors measure visible, visible red, IR, and UV radiation, as well as surface temperature and radiance. Microphysics, physics, and chemistry are important parts of this experiment. The different sensors and analyzers monitor the liquid water content in clouds, the concentration and size distribution of aerosols, the average concentration and fluctuations of $\mathrm{O}_{3}$, the concentrations of nitrogen oxides (NO$\left.\mathrm{NO}_{2}-\mathrm{NO}_{y}\right), \mathrm{CO}_{2}, \mathrm{CO}$, and VOC. The relaxed eddy accumulation technique, developed for the EXPRESSO campaign, was used to measure $\mathrm{CO}_{2}$ and isoprene turbulent fluxes averaged on horizontal low-altitude flight legs of about $30 \mathrm{~km}$. Two sampling lines were devoted to isokinetic sampling of aerosols.

During the 12 operational days of the aircraft campaign, 11 scientific flights were made (totaling 24 hours), partly over the Boali savanna (60 km northwest from Bangui, three 
Table 2. Dynamic Thermodynamic, Radiometric, and Chemistry Measurement Systems Installed on Board the Research Aircraft Fokker 24 (ARAT) and Operated During the EXPRESSO Experiment

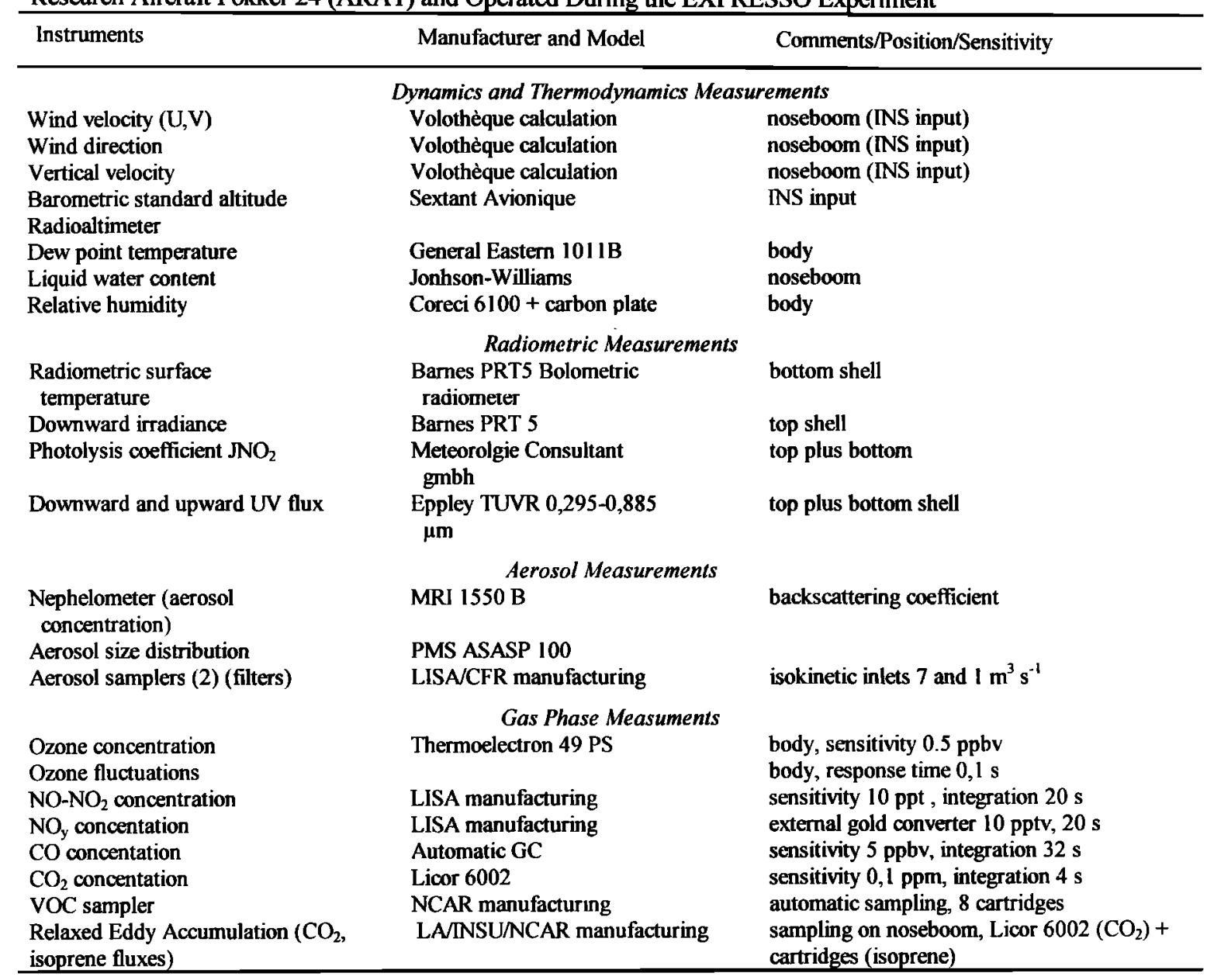

flights: $44,45,51)$, and partly over the Enyélé rain forest (120 km south of Bangui, four flights: $46,47,49,52$ ) (Table 3). Two transect flights were made, one to study the evolution of air masses in the Harmattan layer (flight 48) and one to fly over the Bomassa-Ndoki ground station in the northern Congo (flight 50). A test flight at the beginning of the campaign was made west of Bangui (43), and a last flight at the end of the campaign was made across the savannaforest interface (Figure 7). Flights were carried out between 1100 and 1300 local time, the period of highest energy and fully developed boundary layer. Flight paths over the Boali savanna and the Enyele forest had the same pattern to study vertical exchanges from the surface to the free troposphere up to $4 \mathrm{~km}$ altitude. These flights included stabilized flight legs of about $30 \mathrm{~km}$ perpendicular to the mean wind direction: three low-altitude legs at about $100 \mathrm{~m}$ above ground level, one leg in the middle of the boundary layer, three legs at the top of the boundary layer, and two or three legs above.

The data collected on the aircraft allowed investigation of the following: (1) energy and mass balance in the homogeneous boundary layer over the savanna and the forest as well as turbulent kinetic energy budget and entrainment of air masses at discontinuity surfaces, (2) concentrations of $\mathrm{NO}_{x}, \mathrm{NO}_{y}$, and $\mathrm{O}_{3}$ as well as $\mathrm{O}_{3}$ deposition flux onto the forest and savanna canopies to retrieve the $\mathrm{O}_{3}$ budget at regional scale, (3) VOC and isoprene fluxes above savanna and forest, (4) concentrations of $\mathrm{CO}$ to provide a tracer of fire activity, and (5) particle concentration, size distribution, and chemical composition.

\subsection{Vegetation Fire Studies}

The satellite monitoring of biomass burning during the IGAC EXPRESSO experiment was performed by the Monitoring Tropical Vegetation Unit of the Joint Research Center. This work helped assess the fluxes of trace gases and aerosols emitted by dry season central African savanna fires. The study area covers the transition zone between the savanna and the forest domains. Satellite remote sensing is the only technology that allows consistent data collection of the spatial and temporal distribution of fires at the scale required by the EXPRESSO experiment.

A portable monitoring system was developed and operated, in collaboration with the ORSTOM and NRI Institutes in central Africa for the in situ, real-time acquisition and processing of NOAA-AVHRR imagery [Belward et al., 1993; Janodet et al., 1996]. The acquisitions were initiated in December 1993 and ended in December 1996. A total of 1058 acquisitions were made during this period, establishing a database of satellite imagery over almost four burning seasons. 
Table 3. List and Characteristic of Experimental Flights Performed During the EXPRESSO Experiment Between November 21 and December 2, 1996, Over Southern CAR and Northern

\begin{tabular}{|c|c|c|c|c|c|}
\hline Flight & Date & $\begin{array}{l}\text { Hours, } \\
\text { UT }\end{array}$ & ITCZ & Type of Experiment & Comments* \\
\hline 43 & Nov. 21 & $1223-1409$ & $79 \mathrm{~N}$ & $\begin{array}{l}\text { Savanna West to } \\
\text { Bangui }\end{array}$ & $\begin{array}{l}\text { No } \mathrm{CO}_{2} \text { and } \mathrm{VOC} \\
\text { sampling, discontinuous } \mathrm{O}_{3} \\
\text { recording }\end{array}$ \\
\hline 44 & Nov. 22 & 0954-0118 & $7^{\circ}-8^{\circ} \mathrm{N}$ & Boali savanna & $\begin{array}{l}\text { discontinuous } \mathrm{O}_{3} \\
\text { recording }\end{array}$ \\
\hline 45 & Nov. 24 & $0934-1138$ & $8^{\circ} \mathrm{N}$ & Boali savanna & \\
\hline 46 & Nov. 25 & $0927-1142$ & $7^{\circ}-8^{\circ} \mathrm{N}$ & Enyele forest & $\begin{array}{l}\text { discontinuous } \mathrm{CO}_{2} \\
\text { recording }\end{array}$ \\
\hline 47 & Nov. 26 & $0930-1145$ & $7^{\circ}-8^{\circ} \mathrm{N}$ & Enyele forest & \\
\hline 48 & Nov. 27 & $1057-1319$ & $7^{\circ}-8^{\circ} \mathrm{N}$ & $\begin{array}{l}\text { gradient in Harmattan } \\
\text { layer }\end{array}$ & \\
\hline 49 & Nov. 28 & 0953-1156 & $7^{\circ}-8^{\circ} \mathrm{N}$ & Enyele forest & \\
\hline 50 & Nov. 29 & 0922-1139 & $7^{\circ}-8^{\circ} \mathrm{N}$ & Bomassa forest & \\
\hline 51 & Nov. 30 & $0958-1216$ & $6^{\circ}-7^{\circ} \mathrm{N}$ & Boali savanna & $\begin{array}{l}\text { discontinuous } \mathrm{CO}_{2} \\
\text { recording }\end{array}$ \\
\hline 52 & Dec. 1 & $0929-1151$ & $6^{\circ} \mathrm{N}$ & Enyele forest & \\
\hline 53 & Dec. 2 & $0836-1037$ & $4^{\circ}-5^{\circ} \mathrm{N}$ & $\begin{array}{l}\text { forest-savanna } \\
\text { interface }\end{array}$ & \\
\hline
\end{tabular}

* Flights 44, 45, 51 (Boali savanna) and 46, 47, 49, 52 (Enyele forest) were dedicated to the study of turbulence and vertical exchanges between boundary layer and free troposphere over homogeneous areas of savanna and rain forest. During the 11 flights, all instrumentation for dynamics, thermodynamics, radiation, aerosols, and gas phase chemistry measurements worked except for those mentioned in this column. Six cartridges for VOC analysis were sampled during each flight along with four to five filters for determination of the chemical composition of aerosol. Three to five REA sampling for $\mathrm{CO}_{2}$ and isoprene flux determination were performed on each flight.

The in situ availability of daily fire maps was not only directly used for quantifying fluxes, but also to help in the guiding and planning of airborne campaigns. The 1994 and 1995 pre-EXPRESSO campaign used the near real-time availability of AVHRR fire maps to identify regions of intense fire activity and guide fire detection verification and validation air surveys. These used GPS systems to locate fires and multispectral video cameras to characterize fire size and front morphology from aircraft. The portable monitoring system was operated in central Africa for the in situ, realtime acquisition and processing of NOAA-AVHRR imagery during the EXPRESSO dry season field campaign, which lasted from October 1, 1996, to December 2, 1996. One AVHRR scene per day was processed to locate active fires and burned areas. A set of 25 images, acquired between October 31 and December 2, 1996, was analyzed to detect active fires and burned surfaces. The images were preprocessed to eliminate radiometric noise, and clouds were screened with the multiple threshold algorithm used in the production of the IGBP-DIS global fire product. Active fires were detected with the IGBP-DIS contextual algorithm, and burned surfaces were mapped using a procedure based on GEMI3, a modified version of the Global Environmental Monitoring Index (GEMI), which is highly sensitive to the presence of burned surfaces and strongly resistant to the atmospheric effects of smoke aerosols. Daily estimates of fire occurrence were produced and mapped to represent the spatial dynamics of biomass burning during the campaign. Fire distribution information was coupled with other databases that provide (1) fuel load retrieved from satellite data coupled with a net primary production model and (2) burning efficiency and emission factors so that trace gas fluxes could be estimated. Fluxes were then integrated regionally on the basis of the daily maps of burned areas.

\subsection{Modeling}

Previous campaigns in the last decade have highlighted the difficulty of establishing the interactive role of fluxes, transport, chemical transformations, and removal of gases and particles in the tropical troposphere. Modeling is complicated because major processes in the atmosphere act on a wide range of spatial and temporal scales, so that assessment of the net effect is difficult. The objectives of the EXPRESSO modeling studies are to (1) help to understand and interpret the EXPRESSO field measurements, (2) provide a framework for using EXPRESSO measurements to initialize, validate, and further refine atmospheric transport/chemistry models in tropical zones, and (3) characterize the emissions from biomass burning in the savanna and from the equatorial forest and assess their importance on atmospheric chemistry at local, regional, and global scales.The studies include two major modeling topics: (1) process modeling of surface exchanges, using hydrocarbon flux models, and emission fluxes from soil and (2) large-scale comprehensive modeling that includes the following:

1. A regional model is used to couple emissions, chemistry, and transport. Emphasis will be on quantifying the sources and sinks that are regionally driven by convection, vertical exchanges between the boundary layer and the free troposphere, horizontal transport in the vicinity of the ITCZ, and exchanges between savanna and forest zones. The meteorology is simulated using a three-dimensional mesoscale model, Regional Atmospheric Modeling System (RAMS) in its nonhydrostatic version [Pielke et al., 1992]. This model is also used to compute the distribution of a chemical tracer (CO) characteristic of biomass buming source estimates. The model is initialized with gridded maps 


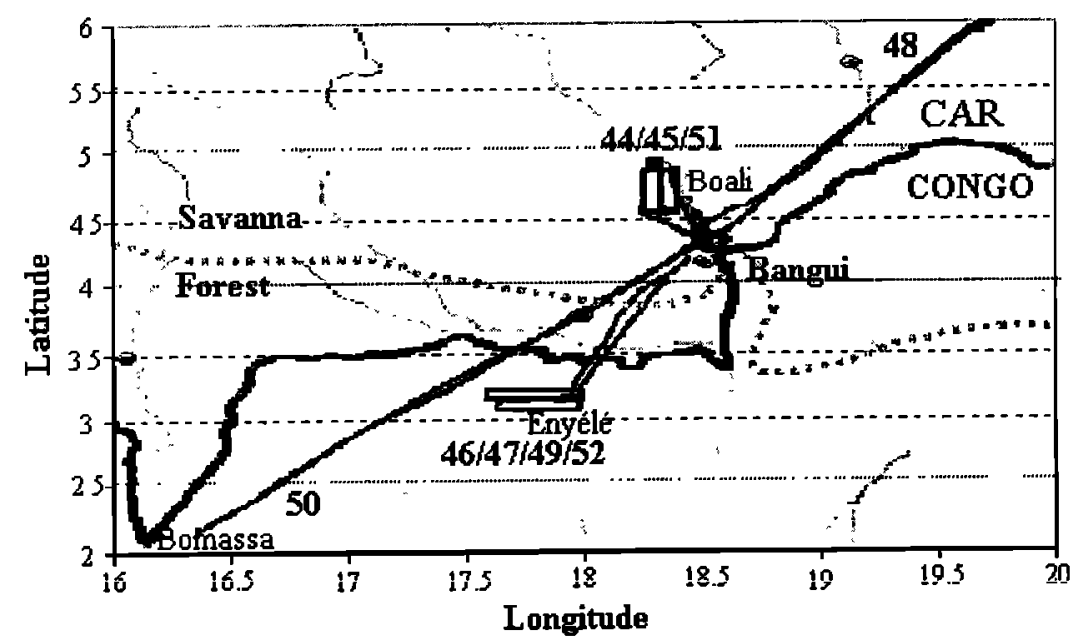

Figure 7. Flight areas during the EXPRESSO campaign. Flight numbers are specified under each flight track (thin lines). The thick line correspond to the frontier between CAR and Congo.

of $\mathrm{CO}$ fluxes retrieved from satellite data. The distributions obtained are compared with aircraft observation in order to improve biomass burning sources. In a second step, this model will be coupled with a chemical module to simulate the photochemistry over the entire EXPRESSO region.

2. The Model for Ozone And Related chemical Tracers (MOZART) model [Brasseur et al., 1996] is dedicated to a global analysis. It simulates the distribution of 29 species on the global scale from the surface to the upper stratosphere with a resolution of $2.8^{\circ} \times 2.8^{\circ}$ in the horizontal.

3. Interactive regional/global modeling to bridge the gap between large-scale and subgrid-scale phenomena through nesting techniques, zooming techniques, and budgets, or yield calculations, is achieved with a third model [Ginoux and Brasseur, 1997]. This model is able to solve the equations on an irregular grid which allows it to use a $50 \mathrm{~km}$ resolution over central Africa and $1000 \mathrm{~km}$ over the Pacific. The distribution of 46 species is computed over the period covering the EXPRESSO measurements.

\subsection{EXPRESSO Database}

A global database has been developed to provide EXPRESSO investigators with a centralized tool for data management, and help collaborations, with the final objective of ensuring the largest distribution of EXPRESSO data to the scientific community. The EXPRESSO database contains the following (1) data collected during EXPRESSO observation periods (ground, airborne, and satellite measurements) and validated by principal investigators; (2) meteorological data from ground stations, and inputs and outputs from ECMWF model (wind, temperature, humidity, vorticity and divergence fields, back trajectories); and (3) satellite products derived from data collected during preparation period (three dry seasons).

The distribution of data is done with two complementary means: (1) WWW server which provides on-line access to catalogue and documentation, an extraction interface allowing the importation of data sets according to different criteria and display capabilities to assist the users in data set selection, and (2) CD-ROMs gathering validated archive data which have the same functions as the WWW server.
The MEDIAS (MEDItérranée et Afrique Subtropical) Research Center is in charge of the development and administration of the database under the responsibility of the EXPRESSO manager. The EXPRESSO database will be opened to the scientific community in 1999.

\section{Outline of the Main Results}

Following the STARE/SAFARI experiment in southern African tropics, the EXPRESSO experiment highlights the impact of tropical sources of trace gases and particles on the chemical composition of the atmosphere. This experiment combined ground-based, aircraft, and remote sensing measurements, allowing investigation of surface fluxes of energy and trace gases from both savanna and forest ecosystems on one hand, and photochemical and dynamic processes in the lower atmosphere on the other hand. Several results can be emphasized:

1. The energy balance of both ecosystems is primarily determined by evaporation (latent heat flux) with Bowen ratios of the order of $\mathbf{0 . 2}$ and $\mathbf{0 . 4 5}$ over forest and savanna, respectively. The kinetic energy budget in the boundary layer is dominated by thermal (versus dynamic), production. This may be due to very weak horizontal winds in the vicinity of the ITCZ, in spite of the strong roughness of both ecosystems (Delon et al., unpunblished manuscript, 1999a). The location of the experimental domain, at the interface between savanna and forest ecosystems and in the middle of the ITCZ, results in a great complexity of dynamic fields as shown by air mass back trajectories, calculated from ECMWF model, in the boundary layer and the free troposphere. This complex circulation is quite well simulated by the three-dimensional mesoscale model RAMS which reproduce the main jets, that is, Harmattan and monsoon flows, as well as divergence and convergence areas. In addition, the model is able to simulate a vegetation breeze, induced by diurnal temperature gradients at the savannaforest interface, which may play a significant role in horizontal exchanges between both ecosystems [Cautenet et $a l$., this issue]. Vertical exchanges between the boundary layer and the free troposphere (monsoon and Harmattan 


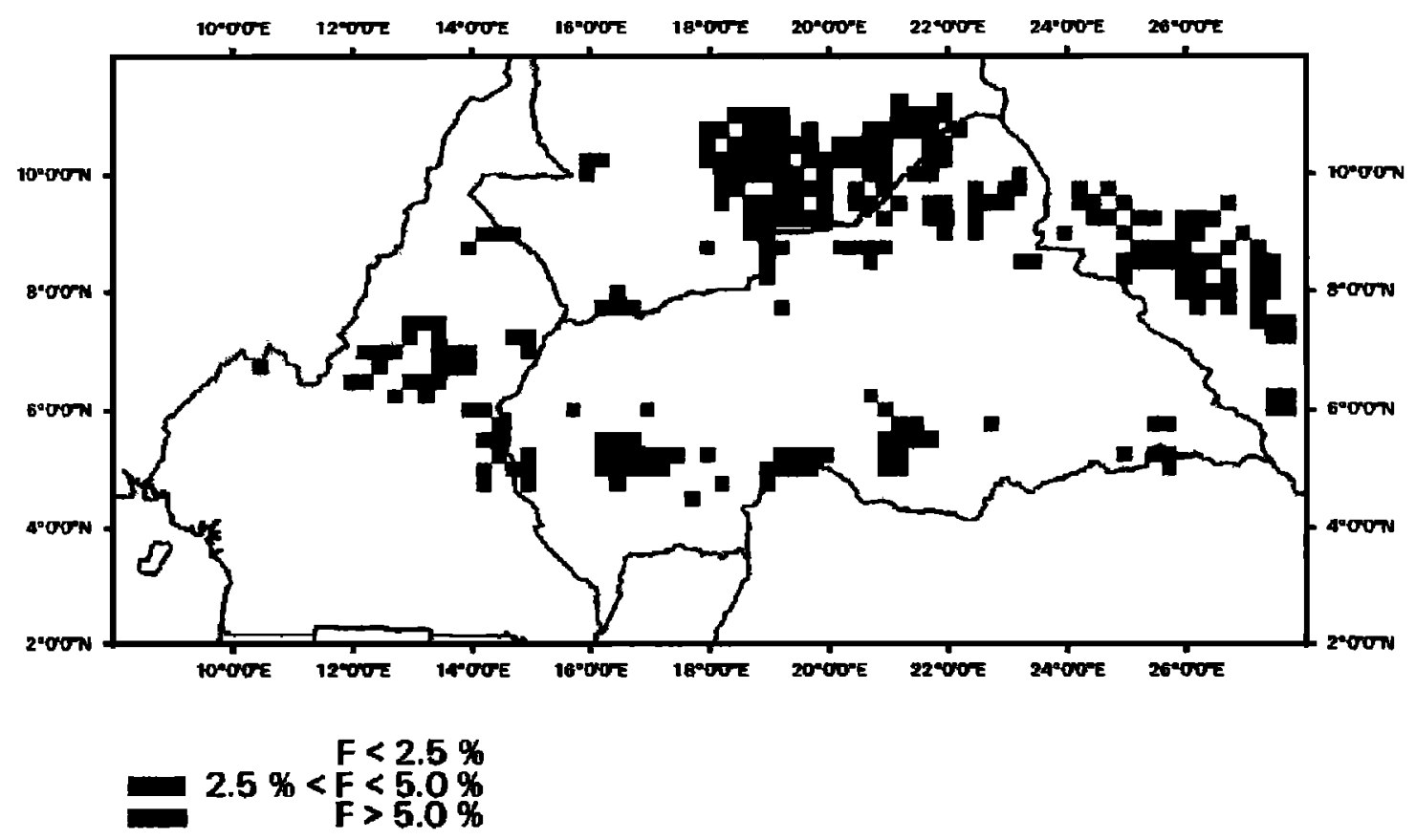

Figure 8. Detection of active fires during the dry season field experiment: percentage of AVHRR pixels detected as fire pixels in $0.25^{\circ} \times 0.25^{\circ}$ cell for 25 days between October 31 and December 2, 1996. [Pereira et al., this issue; Grégoire et al., 1998].

flows) would result from a diversity of processes occurring at various scales as suggested by Delon et al., (unpublished manuscript, 1999a). They include (1) small-scale processes such as entrainment, penetrative dry convection, waves and wave breaking, boundary layer clouds, and shear wind turbulence, (2) mesocale processes such as organized cloud coverage, local divergence-convergence field, penetrative cloudy convection, and (3) synoptic-scale processes linked to subsidence and ascendance.

2. A high density of fires was observed in savanna areas (J. M. Gregoire and S. Pinnock, unpublished manuscript, 1999) where the average number of fires detected every day in the "EXPRESSO window" is about 5000 with corresponding burned areas of $15,000 \mathrm{~km}^{2} /$ day [Peirera et al., this issue] (Figure 8). The Rose Diagram approach has been applied to the regional maps of fires, in order to improve our understanding of the relationships between the spatial distribution of fires and the atmospheric chemistry measurements performed at experimental sites (P. A. Brivio et al., unpublished manuscript, 1999). Moreover, a preliminary assessment of vegetation fuel moisture within the EXPRESSO study area has been initiated by P. Ceccato and S. Flasse (unpublished manuscript, 1999). The 10-years archive of NOAA-AVHRR data available at MTV was used for this analysis.

3. The consequence of the intense fire activity in savanna areas is the high level of pollution observed at regional scale. For instance, regional concentration fields of $\mathrm{CO}$ and $\mathrm{NO}_{\mathrm{y}}$ are in the ranges $250-400 \mathrm{ppb}$ and 4-10 ppb, respectively, and average concentrations of benzene $(0.5 \mathrm{ppb})$ and black carbon $\left(10 \mu \mathrm{g} \mathrm{m}^{-3}\right)$ illustrate the overwhelming influence of biomass burning on the chemical composition of the lower troposphere. Aircraft data taken over the forest and groundbased measurements taken at the forest site showed that biomass burning pollution widely contaminates the forest atmosphere. Biomass burning emissions were determined from (1) direct estimates of burned areas based on new remote sensing algorithms [Pereira et al., this issue], (2) aboveground biomass density derived from satellite data coupled with a net primary production model (S. Cherchali et al., unpublished manuscript, 1999), and (3) burning efficiency and emission factors from literature. All these parameters present rather large uncertainties. To better constrain this dominant source, the redistribution of $\mathrm{CO}$, considered an inert tracer of biomass burning, has been simulated using a 3-D nonhydrostatic mesoscale model coupled with an inert tracer emission module. The objective was to compare the $\mathrm{CO}$ distribution in the lower troposphere produced by the model with vertical profiles of $\mathrm{CO}$ concentration obtained from aircraft measurements, in order to assess the sensitivity to the magnitude and location of sources in redistribution of an inert tracer like $\mathrm{CO}$ and to constrain flux estimates. Estimated fluxes have to be divided by a factor of 2 to retrieve $\mathrm{CO}$ concentration fields consistent with aircraft observations.

4. The EXPRESSO study included a number of field experiments designed to improve our ability to predict isoprene emissions within the EXPRESSO study domain. The field experiments include enclosure measurements, and tower and aircraft based above-canopy measurements [Klinger et al., 1998; D. Serca et al., unpublished manuscript, 1999; Vierling et al., unpublished manuscript, 1999, J. P. Greenberg et al., unpublished manuscript, 1999]. Above-canopy flux measurements at the Ndoki forest site characterized diurnal and seasonal flux variations that were complemented by a regional spatial integration over the forest and the savanna provided by flux measurements using an airborne REA system (C. Delon et al., unpublished 
manuscript, 1999b). Mean isoprene fluxes observed with the aircraft system were approximately $1200 \mu \mathrm{g}(\mathrm{C}) \mathrm{m}^{-2} \mathrm{~h}^{-1}$ over the forest and $500 \mu \mathrm{g}(\mathrm{C}) \mathrm{m}^{-2} \mathrm{~h}^{-1}$ over the savanna (J. P. Greenberg et al., unpublished manuscript, 1999). In comparison, isoprene fluxes measured with the tower-based REA system over the forest ranged from nearly zero at night to over $1000 \mu \mathrm{g}(C) \mathrm{m}^{-2} \mathrm{~h}^{-1}$ in the middle of the day (D. Serca et al., unpublished manuscript, 1999). These results were then synthesized with other recent work to produce improved estimates of isoprene emission from central Africa [Guenther et al., this issue]. The new estimate of annual total isoprene emission for the EXPRESSO region is only slightly lower than the previous estimate of Guenther et al. [1995]. However, the spatial and temporal variations are considerably different. The EXPRESSO field measurements tend to indicate that the emission model can probably provide a reasonable average estimate of isoprene emission, but that there are some observed spatial and seasonal variations which are not well represented in the model. Therefore we expect that the uncertainty associated with the annual average emission estimate for the entire domain (about a factor of 3) is much less than the uncertainty associated with a particular time and location.

5. Ozone and nitrogen oxides data allow the characterization of air masses in relation to $\mathrm{O}_{3}$ production efficiency (OPE). In the planetary boundary layer (PBL), high values of OPE are observed. They increase with photochemical age of the air mass so that OPE is lower in the Harmattan layer (T. Marion and P. E. Perros, unpublished manuscript, 1999). To complement the $\mathrm{O}_{3}$ budget of the $\mathrm{PBL}, \mathrm{O}_{3}$ fluxes were measured from the aircraft at low altitude over the savanna and the forest. Average deposition velocities were 0.7 and $1.5 \mathrm{~cm} \mathrm{~s}^{-1}$, respectively, and a linear relationship was observed between $\mathrm{O}_{3}$ dry deposition velocity and leaf area index (B. Cros et al., unpublished manuscript, 1999)

6. Isolating the respective roles of emissions, chemistry, and transport processes in the distribution of trace constituents and regional photochemistry must be done through multistep modeling exercises. The first step was to evaluate and calibrate model outputs versus dynamic and thermodynamic data provided by aircraft measurements, and the second step was to incorporate and validate biomass burning emissions [Cautenet et al., this issue]. The third step will be to introduce biogenic emissions into the chemistry and transport models and determine the impact of the revised emission estimates [Guenther et al., this issue]. The final step will be to use both mesocale and global models coupled with appropriate chemical modules to simulate and understand photochemistry and transport at regional and global scales.

\section{Conclusion}

The importance of the tropics on the chemical composition of the global atmosphere has been recognized for more than 15 years. The EXPRESSO field campaigns provide an original data set allowing improved description and better understanding of atmospheric chemistry in the northern African tropics. EXPRESSO complements the experiments conducted since the mid-1980s, including GTE/ABLE 2A (1985) [Harris et al., 1988] in the Amazon, and DECAFE
(1998, 1991) [Fontan et al., 1992; Lacaux et al., 1995], and STARE/SAFARI (1992) [Lindesay et al., 1996] in Africa. New experiments are underway in the Amazon in the framework of the Large Scale Biosphere-Atmosphere Experiment in Amazonia (LBA), and CLAIRE (Cooperative LBA Airborne Regional Experiment) programs [Andreae et al., 1998; Grégoire et al., 1998]. The results gained from EXPRESSO allow not only the documentation and parameterization of biogenic and biomass burning sources, but also the study of exchange processes of energy and trace compounds in the region of the ITCZ. Because of experimental constraints linked to the capabilities of the aircraft used, investigations were limited to $4 \mathrm{~km}$ altitude; however, model components can be evaluated using the experimental results. On the basis of the understanding gained from this work, improved submodels will be developed and implemented in regional- and global-scale chemistry and transport models. This modeling effort will lead to better understanding of the chemistry of the upper tropical troposphere which is essential to assess the oxidation capacity of the global atmosphere. The tropical troposphere is strongly affected by cloud convection which favors fast vertical transfers of $\mathrm{O}_{3}$ precursors produced by the continental biosphere $\left(\mathrm{CO}, \mathrm{VOC}\right.$, and $\mathrm{NO}_{\mathrm{x}}$ ) within the rising branches of the Walker cells. These compounds drive $\mathrm{O}_{3}$ production in the middle and upper troposphere [Jacob et al., 1996]. A significant impact on the stratosphere is also expected. Finally, in these regions, heterogeneous phase chemistry within convective clouds, assumed to be important, is almost unknown. Following EXPRESSO, our future experimental projects in the tropics will focus on the impact of deep convection on the chemistry of the upper troposphere and lower stratosphere.

\section{References}

Andreae, M. O., The CLAIRE 98 Science Team, Cooperative LBA Airborne Regional Experiment 98 - Overview and first results. Fith Scientific Conference of the Intermational Global Atmospheric Chemistry Project (IGAC), Seattle, USA, August 1925,1998

Belward, A.S., J.-M. Gregoire, G. DeSouza, S. Trigg, M. Hawkes, J.M. Brustet, D. Serca, J-L. Tireford, J.-M Charlot, and R. Vuattoux, In-situ,real-time fire detection using NOAA/AVHRR dala, paper presented at 6th AVHRR Data Users' Meeting, Belgirate, Italy, June 28 to July 2, 1993.

Brasseur, G. P., D. A. Hauglustaine, and S. Walters, Chemical compounds in the remote Pacific troposphere. Comparison between MLOPEX

measurements and chemical transport model calculations, $J$. Geophys. Res., I0I, 14,795-14,813, 1996.

Braswell, B. H., D. S. Schimel, J. L. Privette, B. Moore III, W. J. Emery, E. W. Sulzman, and A. Hudak, Extracting ecological and biophysical information from AVHRR optical data. An integrated Algorithm based on ion inverse modeling, J. Geophys. Res., I0I, 23,335-23,348, 1996.

Brivio, P. A., J.-M Grégoire, B. Koffi, and G. Ober, Use of rosediagram method for vegetation fire pattern analysis at regional scale in Africa, in Geoscience and Water Resources: Environmental Data Modeling., edited by C Bardinet and J. J. Royer, pp 159-164, Springer-Verlag, New York, 1997

Businger, J. A., and A. C. Delany, Chemical sensor resolution required for measuring surface fluxes by three common micrometeorological techniques, J. Atmos. Chem., I0, 399-410, 1990.

Cachier, $H_{\text {., }}$ and J. Ducret, Influence of biomass buming on equatorial African rains, Nature, 352, 228-230, 1992. 
Cautenet, S., D. Poulet, C Delon, R.A. Delmas, J.M. Gregoire, J M. Pereira, S. Cherchali, O. Amram, and G. Flouzat, Simulation of carbon monoxide redistribution over central Africa during biomass burning events (EXPRESSO experiment), J. Geophys. Res., this issue.

Cros, B., D. Nganga, A. Minga, J. Fishman, and V. Brackett, Distribution of tropospheric ozone at Brazzaville, Congo, determined from ozonesonde measurements, J. Geophys. Res., $97,12,869-12,875,1992$.

Crutzen, P.J., A.C. Delany, J. Greenberg, P. Haagenson, L. Heidt, R. Lueb, W.H. Pollock, W. Seiler, A. Wartburg, and P. R. Zimmerman, Tropospheric chemical composition measurements in Brazl during the dry season, J. Atmos. Chem., 2, 233-256, 1985

Crutzen, P.J., and R. Carmichael, Modeling the influence of fires on atmospheric chemistry, in Fire in the Environment: The Ecological and Climatic Influence of Vegetation Fires, edited by P. J. Crutzen and J. G. Goldammer, John Wiley, New York, 1993.

Delmas, R., J. P. Lacaux, J. C. Menaut, L. Abbadie, X. Le Roux, G. Helas, and $J$. Lobert, Nitrogen compound emission from biomass burning in tropical African savanna, FOS/DECAFE Experiment (Lamto, Ivory Coast), J. Atmos. Chem., 22, 175-194, 1995.

Ehrlich, D., J.-M. Grégoire, H. Eva, E. Janodet, and B. Koffi, Fire detection, land cover characterization and burnt area estimation in the savannah-forest transition zone of central Africa, Publ. EUR $16314 E N$, pp. 72, Eur. Communities, Luxembourg, Brussels, 1995.

Fishman, J., and J. C. Larsen, The distribution of total ozone and stratospheric ozone in the tropics: Implications for the distribution of tropospheric ozone, J. Geophys. Res., 92, 6627-6634, 1987.

Fishman, J., C. E. Watson, J C. Larsen, and J. A. Logan, Distribution of tropospheric ozone determined from satellite data, J. Geophys. Res., 95, 3599-3617, 1990

Fishman, J., J. M. Hoell Jr., R. D. Bendura, R. J. McNeal, and V. W.J. H. Kirchhoff, NASA GTE TRACE A Experiment (September-October 1992), J. Geophys. Res., 10I, 23,86523,879, 1996.

Fontan, J., A. Druilhet, B. Benech, R. Lyra., and B. Cros, 1992, The DECAFE Experiments: overview and meteorology, $J$. Geophys. Res. 97, 6123-6136

Ginoux, P., and G. Brasseur, Three-dimensional regional modeling studies of the transport and photochemistry related to the EXPRESSO field campaign, Eos Trans. $A G U, 78$ (46), Fall Meet. Suppl , 92, 1997

Greenberg, J-P., P.R. Zimmerman, L. Heidt, and W. Pollock, Hydrocarbon and carbon monoxide emissions from biomass burning in Brazil, J. Geophys. Res., 89, 1350-1354, 1984.

Grégoire, J.-M., B. Glénat, P. Janvier, E. Janodet, A. Toumier, and J.M.N. Silva, Fire activity in the Guiana Shield, the Orinoco and Amazon basins during March 1998, Publ. EUR 18091 EN, 22 pp., Joint Res. Cent. Eur. Comm.; Ispra, Italy, July 1998.

Guenther, A., et al., A global model of natural volatile organic compound emissions, J. Geophys. Res., 100, 8873-8892, 1995.

Guenther, A., W. Baugh, K. Davis, G. Hampton, P. Harley, L. Klinger, L. Vierling, and P. Zimmerman, Isoprene fluxes measured by enclosure. relaxed eddy accumualtion, surface layer gradients, mixed layer gradients, and mixed layer mass balance techniques, $J$. Geophys. Res., 101, 18,555-18,567, 1996.

Guenther, A., B. Bauth, G Brasseur, J. Greenberg, P. Harley, L. Klinger, D. Serca, and L. Vierling, Isoprene emission estimates and uncertainties for the central African ESPRESSO study domain, J. Geophys. Res., this issue.

Hamulton, A., African forests, in Tropical Rain Forest Ecosystems, Ecosyst. World, vol 14B, edited by H. Leith, and M. J. A Werger, pp. 155-182, Elsevier, New York, 1989.

Harriss, R.C, et al, The Amazon Boundary Layer Experiment (ABLE 2A): Dry season 1985, J. Geophys. Res., 93, 1351-1360, 1988.

Helas, G., H. Bingemer, and M. O. Andreae, Organic acids over equatorial Africa. Results from DECAFE 88, J. Geophys. Res., 97, 6187-6193, 1992.

Jacob, D. J., et al., Origin of ozone and $\mathrm{NO}_{\mathbf{x}}$ in the tropical troposphere: A photochemical analysis of arrcraft observations over the South Atlantic Basin, J. Geophys. Res., 101, 24,235$24,250,1996$.

Janodet, E., A. Tournier, S. Brownlee, B. Glénat, and J.-M. Grégoire, Software package developed and implemented by MTV-SAI for the Pre-Processing and processing of NOAA-AVHRR images acquired with a portable receiving station, JRC Tech. Note I.96.245, p. 32, Joint Res. Cent. Eur. Comm., Ispra, Italy, Dec. 1996.

Johansson, C., and E. Sanhueza, Emission of NO from savanna soils during rainy season, $J$. Geophys. Res., 93, 14,193-14,198, 1988.

Keller, M., E. Veldkamp, A.M. Weitz, and W.A. Reiners, Effect of pasture age soil trace-gas emissions from a deforested area of Costa Rica, Nature, 365, 244-246, 1993.

Klinger, L. F., J. Greenberg, A. Guenther, G. Tyndall, P. Zimmerman, M. M. Bangui, J. M. Moutsambote, and D. Kenfack, Patterns in volatile organic compound emissions along a savannarainforest gradient in central Africa, J. Geophys. Res., 102, 14431454, 1998.

Lacaux, J. P., R. A. Delmas, B. Cros, B. Lefeivre, and M. O Andreae, Influence of biomass burning emissions on precipitation chemistry in the equatorial forests of Africa, in Global Biomass Burning, edited by J. S. Levine, pp. 167-173, MIT Press, Cambridge, Mass., 1991.

Lacaux, J. P., R. A. Delmas, G. Kouadio, B. Cros, and M. O. Andreae, Precipitation chemistry in the Mayombé forest of equatorial Africa, J. Geophys. Res., 97, 6195-6206, 1992.

Lacaux, J. P., H. Cachier, and R. A. Delmas, Biomass burning in Africa: An overview of its impact on atmospheric chemistry, in Fire in the Environment: The Ecological and Climatic Influence of Vegetation Fires, edited by P. J. Crutzen and J. G. Goldammer, John Wiley, New York, 1993.

Lindesay, J. A., M. O. Andreae, J. G. Goldammer, G. Harris, H. J. Annegarn, M. Garstang, R. J. Scholes, and B. W. Van Wilgen, International Geosphere-Biosphere Programme//nternational Global Atmospheric Chemistry SAFARI-92 field experiment: Background and overview, J. Geophys. Res., 101, 23,521$23,530,1996$.

Liousse, C., J. E. Penner, J. J. Walton, H. Eddleman, C. Chuang, and $\mathrm{H}$. Cachier, Modeling biomass burning aerosols, in Biomass Burning and Global Change, vol. 1, edited by J. S. Levine, pp. 492-508, MIT Press, Cambridge, Mass., 1996.

Marenco A., J. Medale and S. Prieur, Study of tropospheric ozone in the tropical belt (Africa, America) from STRATOZ and TROPOZ Campaigns, Atmos. Environ. 24A, 2823-2834, 1990.

Nganga, D., A. Minga, B. Cros, C. Bouka Biona, J. Fishman, and W B. Grant, The distribution of ozone measured at Brazzaville, Congo, during TRACE A, J. Geophys. Res., 101, 24,095-24,103, 1996.

Nıcholson, S.E., Prediction of trace gas emissions and their climatic impacts: Some geographical considerations, Ecol. Bull., 42, 12$23,1992$.

Pereira, J. M. C., B. S., Pereira, P. Barbosa, S. Stroppiana, M. J. Vasconcelos, and J.-M. Gregoire, Satellite monitoring of fire in the EXPRESSO study area during the 1996 dry season experiment: Active fires, burnt area, and atmospheric emissions, J. Geophys. Res., this issue.

Pickering, K. E., et al., Convective transport of biomass burning emissions over Brazil during TRACE A, J. Geophys. Res., 10I, 23,992-24,012, 1996

Pielke, R.A., W. R. Cotton, R. L. Walko, C.J. Tremback, M. E. Nicholls, M. D. Moran, D. A. Wesley, T. J. Lee, and J. H. Copeland, A comprehensive meteorological modeling system RAMS, Meteorol. Atmos. Phys., 49, 69-91, 1992.

Raven, P.H., Our diminishing tropical forests, in Biodiversity, pp. 119-129, Nat. Acad. of Sci., Washington, D. C., 1988.

Ruellan, S., H. Cachier, A. Gaudichet, P. Masclet, and J. P. Lacaux, Airborne aerosols over central Africa during the EXPRESSO experiment, $J$. Geophys. Res., this issue.

Rodin, L. Y., N. I. Basilevitch, and N.N. Rozov, Production of the World's main ecosystems, in Productivity of the World ecosystems, National Academy of science, Washington, D.C., 1975

Steentoft, M., Flowering plants in West Africa. Cambridge University Press, Cambridge, 1988.

Swaine, M.D. and Hall, J.B., Forest structure and dynamics. In: 
Plant Ecology in West Africa: Systems and Processes (Lawson, G.W., ed.). John Wiley \& Sons, New York, 47-93, 1986

White, F., UNESCO/AETFAT/UNSO vegetation map of Africa, descriptive memoir and map, U. N. Educ., Sci., and Cult. Org., Paris, 1983.

Zimmerman, P. R., J. P. Greenberg, and C. E. Westberg, Measurements of atmospheric hydrocarbons and biogenic emissions in the Amazon boundary layer, J. Geophys. Res., 93, 1407-1416, 1988.

Laboratoire d'Aérologie, OMP, 14 avenue Edoaurd Belin, 31400 Toulouse, France

National Center For Atmospheric Research, Boulder, Colorado, USA, 80307-3000.

Institute of Atmospheric Sciences, Rapid City, South Dakota.

Space Application Institute, Monitoring Tropical Vegetation Unit, I-21020, Ispra, Italy.
Laboratoire Interuniversitaire des Sciences de l'Atmosphère, Faculté de Sciences, Université Paris XII, 61 avenue du Gal de Gaulle, 94010 Créteil Cédex, France.

Laboratoire des Sciences du Climat et de l'Environnement, Bât 12, Campus CNRS, avenue de la Terrasse, 91198 Gif sur Yvette, France.

Laboratoire d'Etude des Systèmes Atmosphériques Multiphasiques, ESIGEC, Université de Savoie, BP 1104, 73376 Le Bourget du Lac Cédex, France.

Laboratoire Associé de Météorologie Physique, Université Blaise Pascal, 63177 Aubière, France.

Université de Brazzaville, BP 69, Brazzaville, Congo.

Natural Ressources Institut, Chatham, U.K.

(Received January 28, 1999; revised April 9, 1999;

accepted April 13, 1999.) 